\title{
Sustainability Evaluation and Analysis of Poverty Alleviation Projects based on Farmer Cooperatives Taking Lianghe County, Yunnan Province as an example
}

\author{
Shao Huimin*1,a, Li Shuang*2,b, Wang Shuzhi ${ }^{3}$, Wang Yujiao ${ }^{4}$ \\ ${ }^{1}$ School of Economics and Management Yunnan Normal University, KunMing, China \\ ${ }^{2}$ Department of Agriculture and Countryside of Yunnan Province, KunMing, China \\ ${ }^{3}$ Pan Asia Business School Yunnan Normal University, KunMing, China \\ ${ }^{4}$ College of Teacher Education, Kunming University, KunMing, China
}

\begin{abstract}
Farmer cooperatives play a huge role in anti-poverty practice, and the results are remarkable. However, there is still room for improvement in the research on the sustainability of poverty alleviation projects of farmers' cooperatives. To this end, the author uses questionnaire surveys, factor analysis and other research methods on the basis of existing research results to analyze the sustainability evaluation dimensions of farmer cooperatives poverty alleviation projects, and builds an evaluation index system. Taking 28 farmer cooperatives poverty alleviation projects in Lianghe County as an example. An empirical analysis of sustainability was carried out, and the following conclusions were drawn: (1)The four common factors of the sustainability evaluation system have greater room for improvement; (2)Cooperatives with poor information technology factors have relatively poor comprehensive scores for the sustainability of poverty alleviation projects. The research results not only help farmers create more material wealth, but also help realize the strategy of rural revitalization. At the same time, it may enrich the theoretical connotation of anti-poverty, and make corresponding theoretical contributions to the theory of rural revitalization and sustainable development.
\end{abstract}

\section{Introduction}

As an important economic carrier of rural development, farmer cooperatives play an important role in poverty alleviation in the field of rural poverty governance, which makes them an ideal carrier for anti-poverty ${ }^{{ }^{1}{ }_{1} 1}$. After the completion of poverty alleviation in 2020, China's antipoverty work will enter a new era, when the poverty problem in rural areas will take on new characteristics. For this reason, whether the poverty alleviation project of farmer cooperatives is sustainable and whether its benefits can be used in the long-term is related to the reexamination of the function of farmer cooperatives to promote poverty.

Regarding the analysis of the sustainability of poverty alleviation projects, scholars have analyzed the ecommerce poverty alleviation project (Wang Zihan, 2018) $\mathbf{I}_{21}$, the passion fruit planting project (Du Jing, 2018) ${ }^{\mathbf{I}_{31} \mathbf{l}}$, the photovoltaic poverty alleviation project (Guo Jianyu, Bai Ting, 2018) ${ }^{\mathbf{I} 4 \mathbf{1}}$, The "New Village" project (Liu Ziyang, Wang Yiduo, 2009) ${ }^{\mathrm{I}^{1} \mathbf{1}}$, the United Nations IFAD Poverty Alleviation Project (Tan Linlin, Shuai Chuanmin, 2007) ${ }^{\mathbf{I}} \mathbf{I}^{\mathbf{I}}$ and other projects analyzed from different perspectives and put forward corresponding countermeasures for different problems. So far, there are few domestic and foreign literatures on the sustainability of poverty alleviation projects of farmer cooperatives. Therefore, this article intends to explore the sustainability dimension of poverty alleviation projects of farmer cooperatives on the basis of existing research results and field investigations, and build a sustainability evaluation system, which will help to better rely on cooperatives to implement poverty alleviation tasks. It has certain academic value and application value.

\section{Construction of sustainability evaluation system for poverty alleviation projects of farmers' cooperatives.}

This paper believes that cooperatives are anti-poverty from three aspects: improving the income, ability, and rights of poor members. At the same time, considering that sustainability is a comprehensive measurement of the effectiveness and function of the organization's operations, the sustainability evaluation of the poverty alleviation project of the farmer cooperative is mainly a measurement of the poverty alleviation function of the cooperative. For this reason, the key to the sustainability of the poverty

b*Corresponding author:381012916@qq.com 
alleviation project of farmers' cooperatives depends on whether the above poverty alleviation goals can be achieved, that is, whether income poverty alleviation, ability poverty alleviation, and rights alleviation are sustainable. Based on the above content, construct the initial indicator system of sustainability evaluation of the poverty alleviation project of farmer cooperatives. The details are as follows:

Table1. Initial indicator system for sustainability evaluation of poverty alleviation projects of farmer cooperatives

\begin{tabular}{|c|c|c|}
\hline Variable & Initial index & Index explanation \\
\hline $\mathrm{C}_{1}$ & $\begin{array}{l}\text { Increase } \\
\text { agricultural } \\
\text { product prices }\end{array}$ & $\begin{array}{l}\text { Compared with before joining } \\
\text { the cooperative, the price of } \\
\text { agricultural products sold by } \\
\text { poor farmers is obvious. }\end{array}$ \\
\hline $\mathrm{C}_{2}$ & $\begin{array}{l}\text { Reduce } \\
\text { marketing costs }\end{array}$ & $\begin{array}{l}\text { Compared with before joining } \\
\text { the cooperative, the marketing } \\
\text { costs of poor farmers are } \\
\text { significantly reduced. }\end{array}$ \\
\hline $\mathrm{C}_{3}$ & $\begin{array}{l}\text { Reduce } \\
\text { production } \\
\text { costs }\end{array}$ & $\begin{array}{l}\text { Compared with before joining } \\
\text { the cooperative, the } \\
\text { production costs of poor } \\
\text { farmers have been } \\
\text { significantly reduced. }\end{array}$ \\
\hline $\mathrm{C}_{4}$ & $\begin{array}{l}\text { Participate in } \\
\text { dividends }\end{array}$ & $\begin{array}{c}\text { Poor members are more likely } \\
\text { to receive surplus distribution } \\
\text { from cooperatives. }\end{array}$ \\
\hline $\mathrm{C}_{5}$ & $\begin{array}{l}\text { Working in a } \\
\text { cooperative }\end{array}$ & $\begin{array}{c}\text { Compared with before joining } \\
\text { the cooperative, the } \\
\text { opportunities for poor farmers } \\
\text { to work in the cooperative are } \\
\text { significantly improved. }\end{array}$ \\
\hline $\mathrm{C}_{6}$ & $\begin{array}{l}\text { Times of } \\
\text { training } \\
\text { obtained }\end{array}$ & $\begin{array}{c}\text { Compared with before joining } \\
\text { the cooperative, the number } \\
\text { of times poor farmers obtain } \\
\text { training has increased } \\
\text { significantly. }\end{array}$ \\
\hline $\mathrm{C}_{7}$ & $\begin{array}{l}\text { Get field } \\
\text { guidance }\end{array}$ & $\begin{array}{l}\text { Compared with before joining } \\
\text { the cooperative, the number } \\
\text { of times that poor farmers } \\
\text { received field guidance } \\
\text { increased significantly. }\end{array}$ \\
\hline $\mathrm{C}_{8}$ & $\begin{array}{l}\text { Improve the } \\
\text { quality of } \\
\text { agricultural } \\
\text { products }\end{array}$ & $\begin{array}{l}\text { Compared with before joining } \\
\text { the cooperative, the quality of } \\
\text { agricultural products } \\
\text { produced by poor farmers has } \\
\text { been significantly improved. }\end{array}$ \\
\hline $\mathrm{C}_{9}$ & $\begin{array}{l}\text { Sell products } \\
\text { through e- } \\
\text { commerce } \\
\text { platform }\end{array}$ & $\begin{array}{l}\text { Compared with before joining } \\
\text { the cooperative, the } \\
\text { proportion of poor farmers } \\
\text { selling products through e- } \\
\text { commerce platform is higher. }\end{array}$ \\
\hline $\mathrm{C}_{10}$ & $\begin{array}{l}\text { Preferential } \\
\text { access to } \\
\text { seedlings }\end{array}$ & $\begin{array}{l}\text { Compared with before join } \\
\text { cooperatives, poor peasant } \\
\text { households to obtain more } \\
\text { favorable seedlings increased. }\end{array}$ \\
\hline $\mathrm{C}_{11}$ & $\begin{array}{l}\text { Preferential } \\
\text { access to } \\
\text { agricultural } \\
\text { materials }\end{array}$ & $\begin{array}{c}\text { Compared with before joining } \\
\text { the cooperative, poor farmers } \\
\text { have more opportunities to } \\
\text { obtain more preferential } \\
\text { agricultural materials. }\end{array}$ \\
\hline $\mathrm{C}_{12}$ & $\begin{array}{l}\text { Access to } \\
\text { agricultural } \\
\text { information }\end{array}$ & $\begin{array}{l}\text { Compared with before joining } \\
\text { the cooperative, poor farmers } \\
\text { have more opportunities to }\end{array}$ \\
\hline
\end{tabular}

\begin{tabular}{|c|c|c|}
\hline & & $\begin{array}{c}\text { obtain more agricultural } \\
\text { information. }\end{array}$ \\
\hline $\mathrm{C}_{13}$ & $\begin{array}{l}\text { Get contract } \\
\text { guarantee }\end{array}$ & $\begin{array}{l}\text { Compared with before joining } \\
\text { the cooperative, the guarantee } \\
\text { of the sales contract for poor } \\
\text { farmers is significantly } \\
\text { enhanced. }\end{array}$ \\
\hline $\mathrm{C}_{14}$ & $\begin{array}{l}\text { Get a small } \\
\text { loan }\end{array}$ & $\begin{array}{c}\text { Compared with before joining } \\
\text { the cooperative, poor farmers } \\
\text { have more opportunities to } \\
\text { obtain micro loans. }\end{array}$ \\
\hline $\mathrm{C}_{15}$ & Land share & $\begin{array}{l}\text { Compared to before joining } \\
\text { the cooperative, it is } \\
\text { obviously easier for poor } \\
\text { farmers to invest land in the } \\
\text { cooperative. }\end{array}$ \\
\hline
\end{tabular}

\section{Materials and Methods}

Lianghe County is one of the key frontier counties and poverty-stricken counties in Yunnan Province's 73 national poverty alleviation and development work. A total of 28 cooperatives were visited in this survey, of which 13 were planting cooperatives, 12 were breeding cooperatives, and 3 were comprehensive cooperatives. A total of 200 questionnaires for poor members were distributed, and 122 valid questionnaires were recovered. The causes of poverty among 122 poor members were 3 orphans, 10 widowed elderly, 27 lost labor, 13 due to illness, and 79 other reasons.

This article uses SPSS23.0 to perform factor analysis on the data. The three indicators of improving the quality of agricultural products $\mathrm{C} 8$, preferential access to agricultural materials $\mathrm{C} 10$, and access to microloans $\mathrm{C}_{13}$ all contribute more than 0.5 to the same common factor, which is not suitable for factor analysis. In addition, only one cooperative in the surveyed cooperative used ecommerce for sales, and the data was not representative, so $\mathrm{C}_{9}$ was deleted. After correction, 11 indicators are selected for factor analysis.

In the analysis of contribution degree, this article mainly adopts the maximum variance orthogonal rotation method. Based on the factor loading matrix after rotation, the exact meaning of the common factor can be obtained, See Table 2 for details.

Table2. Distribution of common factors

\begin{tabular}{ccccc}
\hline Item & $\mathrm{F}_{1}$ & $\mathrm{~F}_{2}$ & $\mathrm{~F}_{3}$ & $\mathrm{~F}_{4}$ \\
\hline $\begin{array}{c}\text { Higher } \\
\text { positive } \\
\text { load }\end{array}$ & $\begin{array}{c}\mathrm{C}_{1} 、 \mathrm{C}_{2} \\
\mathrm{C}_{3} 、 \mathrm{C}_{14}\end{array}$ & $\begin{array}{c}\mathrm{C}_{4} 、 \mathrm{C}_{5} \\
\mathrm{C}_{16}\end{array}$ & $\mathrm{C}_{6} 、 \mathrm{C}_{13}$ & $\mathrm{C}_{7}, \mathrm{C}_{11}$ \\
\hline $\begin{array}{c}\text { Factor } \\
\text { name }\end{array}$ & $\begin{array}{c}\text { Market } \\
\text { factor }\end{array}$ & $\begin{array}{c}\text { Motivation } \\
\text { factor }\end{array}$ & $\begin{array}{c}\text { Information } \\
\text { Technology } \\
\text { Factor }\end{array}$ & $\begin{array}{c}\text { Policy } \\
\text { factor }\end{array}$ \\
\hline
\end{tabular}

It can be seen from Table 4 that the public factors have large loads on indicators $\mathrm{C}_{1}, \mathrm{C}_{2}, \mathrm{C}_{3}$, and $\mathrm{C}_{14}$, which can be classified into one category. These four indicators are reducing marketing costs, reducing production costs, obtaining contract guarantees, and increasing prices of agricultural products. According to the economic significance reflected by the indicators, common factor 1 
can be named a market factor and represented by $F_{1}$. The common factor 2 has a large load on the indicators $\mathrm{C}_{4}, \mathrm{C}_{5}$, and $\mathrm{C}_{16}$ and can be classified as the second category. The three indicators are land equity participation, participation in surplus dividends, and employment in cooperatives. The above three indicators can not only encourage the original poor members to continue to participate in the poverty alleviation project with cooperatives as the carrier, but also attract more farmers to participate, thereby promoting the sustainability of the poverty alleviation project. Therefore, the common factor 2 can be named as the excitation factor, denoted by F2. The common factor 3 is more prominent on the indicators $\mathrm{C}_{6}$ and $\mathrm{C}_{13}$, and it is classified as the third category. These two indicators are the number of training and obtaining more agricultural information. According to the meaning of the indicators, the common factor 3 can be named as the information technology factor, denoted by $\mathrm{F}_{3}$. Common factor 4 has a large load on indicators $\mathrm{C}_{7}$ and $\mathrm{C}_{11}$, which are for preferential acquisition of seedlings and field guidance respectively. Among them, poverty alleviation projects can get seedlings below the market price mostly because of poverty alleviation policies. At the same time, in addition to the agricultural science and technology department of the government department, the government department will also provide field guidance to the members by experts from universities and research institutes. According to its meaning, the common factor 4 can be named as a policy factor, denoted by $\mathrm{F}_{4}$.

The article uses the analytic hierarchy process to determine the weight of the common factors, and invites 9 experts. The weights of sustainability indicators for poverty alleviation projects of farmers' cooperatives are obtained as shown in Table 3:

Table3. Weights of sustainability indicators for poverty alleviation projects of farmers' cooperatives

\begin{tabular}{|c|c|c|}
\hline Target layer & $\begin{array}{c}\text { First level } \\
\text { indicator }\end{array}$ & Secondary indicators \\
\hline \multirow{11}{*}{$\begin{array}{c}\text { Project } \\
\text { sustainability }\end{array}$} & \multirow{4}{*}{$\begin{array}{l}\text { Market factor } \\
(0.4218)\end{array}$} & $\begin{array}{c}\text { Reduce marketing costs } \mathrm{C}_{1} \\
(0.1202)\end{array}$ \\
\hline & & $\begin{array}{c}\text { Reduce production costs } \mathrm{C}_{2} \\
(0.0933)\end{array}$ \\
\hline & & $\begin{array}{c}\text { Get contract guarantee } C_{3} \\
(0.0509)\end{array}$ \\
\hline & & $\begin{array}{c}\text { Increase agricultural } \\
\text { product prices } C_{14} \\
(0.1574)\end{array}$ \\
\hline & \multirow{3}{*}{$\begin{array}{l}\text { Motivation factor } \\
(0.2486)\end{array}$} & Land shareC $C_{4}(0.0497)$ \\
\hline & & $\begin{array}{l}\text { Participate in dividends } \mathrm{C}_{5} \\
(0.1084)\end{array}$ \\
\hline & & $\begin{array}{c}\text { Working in a } \\
\text { cooperative }_{16}(0.0905)\end{array}$ \\
\hline & \multirow{2}{*}{$\begin{array}{l}\text { Information } \\
\text { Technology Factor } \\
(0.1596)\end{array}$} & $\begin{array}{c}\text { Training times } \mathrm{C}_{6} \\
(0.1228)\end{array}$ \\
\hline & & $\begin{array}{c}\text { Get more agricultural } \\
\text { information } C_{13}(0.0367)\end{array}$ \\
\hline & \multirow{2}{*}{$\begin{array}{l}\text { Policy factor } \\
(0.1701)\end{array}$} & $\begin{array}{c}\text { Discount to get seedlingsC } 7 \\
(0.0206)\end{array}$ \\
\hline & & $\begin{array}{l}\text { Get field guidance } \mathrm{C}_{11} \\
(0.1495)\end{array}$ \\
\hline
\end{tabular}

\section{Results discussion and analysis}

The article first uses the analytic hierarchy process to calculate the weights of the 4 common factors, and then uses the straight-line average method to obtain the values of the common factors of each cooperative based on the scores of 122 poor members, and finally uses the weighted average method to obtain the values of each cooperative. The final score and ranking of the sustainability evaluation of poverty alleviation projects. It turns out the sustainability scores and rankings of 28 cooperative poverty alleviation projects. The results show that the sustainability of the Fawangchang Cattle Raising Cooperative, Agaricus blazei Cooperative, and Cattle Raising Cooperative is relatively significant. The poverty alleviation sustainability of Baogu Cooperatives, Pig Breeding Cooperatives, and Young Livestock Breeding Cooperatives is relatively poor. Among the 28 cooperatives, 12 of the cooperative's poverty alleviation projects scored positively, indicating to a certain extent that the cooperative's poverty alleviation results are still good, but there is still room for improvement.

The market factor F 1 mainly reflects the problem of economic income. It mainly increases the income of poor farmers by reducing marketing costs, reducing production costs, obtaining contract guarantees, and increasing agricultural product prices, thereby leading to the sustainable development of poverty alleviation projects. Judging from the ranking of the market factor F1, the Fawangchang Cattle Breeding Professional Cooperative, the Songhong Livestock Breeding Professional Cooperative, and the Chonglou Cooperative are ranked in the top three. The data shows that the above three cooperatives are doing relatively well in this respect, while the beekeeping Cooperatives, pig breeding cooperatives, and young livestock breeding cooperatives have relatively poor results.

The incentive factor $\mathrm{F} 2$ reflects to a large extent the economic rights that poor farmers have obtained by joining the cooperative. Because of the different subjects of economic law, the economic rights enjoyed by them are different. Compared with those who did not participate in cooperatives or other non-members, poor members mainly embody citizens' property rights, labor rights and the right to material assistance by taking shares in land, participating in dividends and working in cooperatives. It shows that the economic rights of the above three cooperatives are doing well. Judging from the score ranking of the incentive factor F2, Agaricus blazei Cooperative, Black Fungus Planting Cooperative and Jiubao Changfeng Vegetable Cooperative are ranked high. The three cooperatives, namely the Alpine Vegetable Cooperative, the Tobacco Planting Cooperative in Bangbie Village, and the Shanghedong White Rape Cooperative, are relatively lagging behind.

The information technology factor $\mathrm{F} 3$ mainly reflects the access to information rights of poor members. Poor members of the community can realize their information access rights mainly through training and obtaining more agricultural information. Judging from the ranking of information technology factor F3, Chamu Cooperative, Pingshan Ecological Tea Cooperative, and Fawangchang 
Cattle Raising Cooperative are the top three, indicating that the operation types of the above three cooperatives are more dependent on technology and market, so they pay more attention to providing information for members .However, Alpine vegetable cooperatives, Youth livestock breeding professional cooperatives and Corn cooperatives ranked lower, while the overall ranking of the above three cooperatives was also relatively backward..

The policy factor F4 mainly reflects the improvement of the ability of poor members. The poor members can improve their ability through preferential access to seedlings and field guidance. From the score ranking of policy factor F4, Gaoshan vegetable cooperatives and Zhixuan tobacco planting professional cooperatives scored higher, which was basically consistent with the conclusion of the actual survey. However, the Tobacco planting cooperatives, Sanhe tea planting cooperatives and Fawangchang cattle raising cooperatives in Bangbie village ranked lower.

\section{Conclusion}

The statistical results show that the four common factors of sustainable evaluation system have a large space for improvement. Of course, this result can also be concluded that the poverty alleviation function of cooperatives has not been fully developed. At the same time, it can also be seen that cooperatives with poor information technology factor have relatively poor comprehensive score of poverty alleviation project sustainability. The empirical analysis shows that the three cooperatives with poor comprehensive scores also have poor information rights factor scores. Of course, the relationship between the two needs to be further confirmed, but it can be inferred that information is very important for cooperatives engaged in agricultural industry. On the contrary, the cooperatives with the highest comprehensive ranking pay more attention to the technical training of their members.

\section{Acknowledgements}

This paper is the result of the stage research on top-notch talents of the 10,000 people program in Yunnan Province. This study was supported by the Natural Science Foundation of China (Grant 71763032), the National Social Science Fund (Grant 19BSH153), and the Start Fund for Doctoral Scientific Research of Yunnan Normal University (Grant 2017RW023).

Funded by the local university joint project of Yunnan Science and Technology Department (project number: 202001BA070001-015, 2019FH001(-073)).

\section{References:}

1. $\mathrm{Xu}$ xuchu. Looking at the function space of farmers' cooperatives from the report of the 19th National Congress of the Communist Party of China. Chinese farmers' cooperatives, 2017 (11): 30

2. Prince Han. Analysis of the Internet plus financial model to enhance the sustainability of the electricity supplier poverty alleviation project: Based on the perspective of supply chain finance and Internet plus asset securitization. Time finance, 2018 (20): 299-300.

3. Du Jing. Research on sustainable development path of agricultural industry poverty alleviation in rocky desertification areas of Guizhou Province -- Based on the practice of passion fruit planting project in Jinshan Village, Kedu Town, Pingtang county. Henan agriculture, 2018 (20): 4-5

4. Guo Jianyu, Bai ting. Discussion on the sustainability of industrial Poverty Alleviation -- Taking photovoltaic poverty alleviation as an example. Economic overview, 2018 (07): 109-116

5. Tan Linlin, Shuai Chuanmin, Zhang Xianfeng. Sustainability evaluation of IFAD poverty alleviation project. Science and technology information development and economy, 2007 (22): 128-129

6. Ministry of agriculture and other nine ministries and commissions. Guidance on the development of characteristic industries in poor areas to promote accurate poverty alleviation [Z]. May 26, 2016

7. $\mathrm{Xu}$ Feng. Farmer cooperatives are the new force of precision poverty alleviation in agricultural industry. Agricultural machinery quality and supervision, 2016. (07): 31-32 